\title{
Compatibility of Biomphalaria tenagophila with Schistosoma mansoni: a study of homologous plasma transference
}

\author{
João R Coelho, Fernando SM Bezerra ${ }^{+}$
}

Departamento de Análises Clínicas e Toxicológicas, Faculdade de Farmácia, Odontologia e Enfermagem, Universidade Federal do Ceará, Rua Cap. Francisco Pedro 1210, 60430-370 Fortaleza, CE, Brasil

This study aims to investigate the importance of the serum factors present in the plasma of resistant Biomphalaria tenagophila snails, when transferred to susceptible conspecific. Susceptible B. tenagophila (CF) received plasma from resistant B. tenagophila (Taim), and both were later infected with Schistosoma mansoni. We noticed that the plasma transfer showed an increase on the resistance of susceptible snails of about $86 \%$ when compared to the nonimmunized group $(p<0.001)$.

Key words: Biomphalaria - Schistosoma mansoni - plasma

Among the endogenous factors involved in snailtrematode interaction, the most important is in relation to the gastropods defense system. This system is different from the vertebrate immune system, as the lymphocytes, immunoglobulins specific antigen are lacking. Nevertheless, the differentiation between the "self" and the "not self" is kept (Bayne 1983). The defense system is made by cellular and humoral elements. The cellular defense system is operated by hemocytes (moving cells), which have phagocytic capacity. The humoral immunity is measured by lectins and opsonins, which are proteins synthesized by hemocytes with specific affinities with carbohydrates (Zelck et al. 1995). Bayne et al. (1980) showed the serum transfer effect of resistant Biomphalaria glabrata on the increase of phagocytic capacity of hemocytes from susceptible snails, demonstrative of interaction between plasmatic factors and the hemocytes during the encapsulation and phagocytic process, that occurred few hours after the miracidium penetration. Although the model $B$. glabrata/S. mansoni has been the object of several studies, the association B. tenagophila/S. mansoni is also a very interesting model because it shows absolute resistance of the snail to the parasite (Coelho et al. 2004). The aim of this study was to evaluate the occurred changes after plasma transference from resistant to susceptible $B$. tenagophila snails following infection with Schistosoma mansoni.

All snails used came from Brazil. Susceptible $B$. tenagophila from Cabo Frio - state of Rio de Janeiro and resistant B. tenagophila from Taim - state of Rio Grande do Sul. The $S$. mansoni LE strain was obtained after passage in hamsters and B. glabrata, at the Federal University of Minas Gerais. Parasites and hosts were kept in the Snail Biology and Parasite Research Laboratory at the Federal University of Ceará, Brazil. The protocol was ba-

\footnotetext{
Financial support: Funcap

+Corresponding autor: bezerra@ufc.br.

Received 8 December 2005

Accepted 31 January 2006
}

sically the same used by Granath and Yoshino (1984), with minor changes, briefly: all B. tenagophila Taim and Cabo Frio strains were anesthetized with sodic pentobarbitol (Nembutal@), 100 mg/2ml) (Martins-Sousa et al. 2001), for $6 \mathrm{~h}$, to relax all the musculature. The plasma for the transference was collected from a hemolymph pool of five $B$. tenagophila - Taim snails. After centrifugation of $80 \mathrm{~g}$ for $10 \mathrm{~min}$ to remove all the hemocytes, it was diluted in sterile PBS in 1:2 proportion. The B. tenagophila - Cabo Frio were inoculated with $5 \mu \mathrm{l}$ of the diluted serum in the cephalopodal region using a $25 \mu 1$ Hamilton Microliter ${ }^{\circledR}$ syringe. The control groups $B$. tenagophila (Taim and Cabo Frio) received the same volume of sterile PBS. Twenty-four hours later, the three groups were individually infected with ten $S$. mansoni miracidia. Six hours later, the groups were replaced in separate aquariums with aeration by pumping and fed with lettuce ad libitum. All the groups were once a week analyzed concerning the cercarial release up to 60 days after infection. The protocol was executed in duplicate. All data were analyzed using chi-square test (Zar 1996).

In this study, we were successful in passively transferring resistance to $S$. mansoni from the resistant $B$. tenagophila (Taim) to the susceptible B. tenagophila (CF) through the plasma (cell-free hemolymph) injection. After 60 days post-infection $86.2 \%$ of the susceptible strains, which received serum from the resistance, were completely protected of a primary infection with the parasite. By the other hand, only $36 \%$ from the non-immunized susceptible snails were not infected, and the control ( $B$. tenagophila-Taim) showed no infection index (Table).

Loker and Bayne (1982) obtained in vitro 57\% of protection when they joined hemocytes of susceptible snails and the serum from the resistant ones. Granath and Yoshino (1984) working with susceptible M-line albino $B$. glabrata that received serum from resistant 10-R2, obtained more than $60 \%$ of protection against $S$. mansoni. Rosa et al. (2005) showed that F1 generation of $B$. tenagophila generated by crossbreeding from $B$. tenagophila Taim and B. tenagophila Joinville (albino) were almost $100 \%$ resistance to the LE strain of S. mansoni.

The plasma of B. glabrata and other planorbid pulmonates contains factors which agglutinate mammalian 
TABLE

Percentage of infection in susceptible Biomphalaria tenagophila Cabo Frio strain after plasma transference from resistance B. tenagophila Taim strain. Snails were individually infected with 10 miracidia of Schistosoma mansoni and exposed 30 and 60 days post- infection to cercarial release

\begin{tabular}{lccccc}
\hline \multirow{2}{*}{$\begin{array}{l}\text { Number } \\
\text { of snails }\end{array}$} & $\begin{array}{c}\text { Days } \\
\text { post-infection }\end{array}$ & $\begin{array}{c}\text { Treatment } \\
\text { schedule }\end{array}$ & $\begin{array}{c}\text { \% infected } \\
\text { snails }\end{array}$ & $\begin{array}{c}\text { \% not infected } \\
\text { snails }\end{array}$ & $\begin{array}{c}\text { Significance } \\
\chi^{2}(\mathrm{p})\end{array}$ \\
\hline 29 & 30 & Imunized & 6.9 & 93.1 & $43.1(<0.001)$ \\
& & Control & 20 & 80 & $18 \quad(<0.001)$ \\
25 & 60 & Imunized & 13.8 & 86.2 & $30.41(<0.001)$ \\
& & Control & 64 & 36 & $3.92(>0.05)$ \\
\hline
\end{tabular}

erythrocytes. These invertebrate hemagglutinins are, in general, multivalent lectins agglutinating red blood cells by linking carbohydrate moieties on neighboring cells, and are likely to function as recognition factors (Loker et al. 1984). Two kinds of recognition receptors have been shown to be present on surfaces of invertebrate hemocytes: receptors which bind directly to foreign cells without mediation of serum factors, and receptors which bind only to particles coated with opsonizing molecules (Renwrantz 1990). Acting in vitro in hemocytes from susceptible snails plasmatic factors will favour the parasite destruction by citotoxicity (Bayne et al. 1980). Fryer and Bayne (1989) detected the agglutinin presence only in the resistant snail's plasma. Zelck and Becker (1992) observed that the pre-incubation of target cells in homologous plasma of resistant snails results in an increase of phagocytic activity hemocytes, even in the plasma absence during the standard analysis. Based on these results we believe that existence of a transferable factor in the serum of $B$. glabrata resistant snails, which specifically activates the hemocytes occurs in B. tenagophila as well. It makes them able to encapsulate and to destroy the parasite.

\section{ACKNOWLEDGEMENTS}

To Dr J Russell Stothard and Dr Fiona Allan from the Natural History Museum, London for their improvement of the English version of the manuscript, and also to Dr Rene D Martins for the statistical analysis support.

\section{REFERENCES}

Bayne CJ 1983. Molluscan immunobiology. In ASM Saleuddin, KM Wilbur (eds), The Mollusca, vol.5, Physiology, Part 2, New York Academic Press, New York, 407 pp.

Bayne CJ, Buckley PM, Dewan PC 1980. Macrophagelike hemocytes of resistant Biomphalaria glabrata are cytotoxic for sporocysts of Schistosoma mansoni in vitro. $J$ Parasitol 66: 413-419.

Coelho PMZ, Carvalho OS, Andrade ZA, Martins-Sousa RL, Rosa FM, Barbosa L, Pereira CAJ, Caldeira RL, JannottiPassos LK, Godard ALB, Moreira LA, Oliveira GC, Franco GR, Teles HMS, Negrão-Corrêa D 2004. Biomphalaria
tenagophila/Schistosoma mansoni interaction: premises for a new approach to biological control of schistosomiasis. Mem Inst Oswaldo Cruz 99: 109-111.

Fryer SE, Bayne CJ 1989. Opsonization of yeast by the plasma of Biomphalaria glabrata (gastropoda): a strain-specific, time-dependent process. Parasitol Immunol 11: 267-278.

Granath WO, Yoshino TP 1984. Schistosoma mansoni: passive transfer of resistance by serum in the vector snail, Biomphalaria glabrata. Exp Parasitol 58: 188-193.

Loker EC, Bayne CJ 1982. In vitro encounters between Schistosoma mansoni primary sporocysts and hemolinfa components of susceptible and resistant strains of Biomphalaria glabrata. Am J Trop Med Hyg 31: 999-1005.

Loker ES, Luy MA, Bayne CJ 1984. Schistosoma mansoni: agglutination of sporocysts, and formation of gels on miracidia transforming in plasma of Biomphalaria glabrata. Exp Parasitol 58: 56-62.

Martins-Sousa RL, Negrão-Corrêa D, Bezerra FSM, Coelho PMZ 2001. Anesthesia of Biomphalaria spp. (Mollusca, Gastropoda): sodium pentobarbital is the drug of choice. Mem Inst Oswaldo Cruz 96: 391-392.

Renwrantz L 1990. Internal defence system of Mytilus edulis. In GB Estefano, Neurobiology of Mytilus edulis, Manchester University Press, Manchester, p. 256-275.

Rosa FM, Godard ALB, Azevedo V, Coelho PMZ 2005. Biomphalaria tenagophila: dominant character of the resistance to Schistosoma mansoni in descendants of crossbreedings between resistant (Taim, RS) and susceptible (Joinville, SC) strains. Mem Inst Oswaldo Cruz 100: 19-23.

Zar JH 1996. Biostatistical Analysis, 3rd ed., Prentice-Hall, New Jersey, $662 \mathrm{pp}$.

Zelck UE, Becker W 1992. Biomphalaria glabrata: influence of calcium, lectins and plasma factors on in vitro phagocitic behavior of hemocytes of noninfected or Schistosoma mansoni-infected snails. Exp Parasitol 75: 126-136.

Zelck UE, Becker W, Bayne CJ 1995. The plasma proteins of Biomphalaria glabrata in the presence and absence of Schistosoma mansoni. Develop \& Comp Immunol 19: 181-194. 